\title{
Medyada Namus Adına İşlenen Cinayetler: Erkek Kurbanlar Üzerine Bir Çalışma
}

\author{
Depiction of Honour Killings in the Media: A Study of Male Victims
}

\begin{abstract}
Nurșen ADAK*
Öz: Bu çalışma, çeşitli kaynaklardan beslenen namus anlayışının medya aracıllğıyla yeniden üretilip üretilmediğini namus cinayetlerinin erkek kurbanlarını konu alan gazete haberleri vasıtasıyla ortaya koymayı amaçlamaktadır. Makale ayrıca namus cinayetlerinin erkek kurbanlarının haberlerde nasıl yer aldıkları, bu haberlerin kadın kurbanlara ilişkin haberlerden farklı bir şekilde sunulup sunulmadığı, şiddeti normalleştirme ve meşrulaştırma biçimlerini de araştırmayı hedeflemektedir. Çalışma kapsamında öncelikle ulusal çapta günlük yayın yapan iki gazetede (Radikal ve Posta) 2012-2014 yıllarında yayınlanan namus cinayeti haberleri taranmıştır ve bu haberler içinde namus adına işlenen cinayetlerden kurbanın erkek olduğu haberler seçilmiştir. Seçilen haberler eleştirel söylem analizi yöntemi kullanılarak çözümlenmiştir. Çözümleme sonucunda kurbanın erkek olduğu namus cinayeti haberlerinde de kurbanın kadın olduğu namus cinayeti haberlerine benzer olarak namus kavramının cinsellik ve kadın bedeni üzerinden tanımlandığı ve ona zarar veren erkeklerin ölümle cezalandırılarak namusun "temizlendiği" vurgulanmaktadır. Namus adına işlenen kadın cinayetlerinin faillerinin büyük çoğunluğunu erkekler oluştururken namus adına öldürülen erkeklerin failleri, namusu "kirletilen" kadınlar veya onların baba, erkek kardeş gibi erkek yakınları olabilmektedir. Araştırmanın çarpıcı verilerinden birisi de haber metinlerinde failin cinayeti namus gerekçesiyle işlediğini belirtilerek toplumdaki saygınlığını yeniden kazanma talebinin vurgulanmasıdır. $\mathrm{Bu}$ durum eril tahakküme dayalı cinsiyetçi şiddet söylemini pekiştirici bir rol oynamaktadır. Ayrıca bazı haber başlıklarında 'namus', 'töre' kavramlarının kullanıldığı da gözlenmiştir. Bu durumun da haber aracilığıyla namus bahaneli cinayetlere ilişkin cinsiyet rejiminin ve cinsiyetçi ideolojinin pekiştirilip yeniden üretilmesine katkı sunduğu iddia edilebilir.
\end{abstract}

Anahtar sözcükler: Toplumsal Cinsiyet, Namus, Kadın, Namus Cinayetleri

Abstract: The aim of this study was to show if the understanding of honour reinforced from different resources was reproduced by the media in news concerning male victims. It also aims to explore how male victims are presented in the news and if this news is presented differently from news about the female victims and the ways of justifying and normalizing this violence. The data for this study concerning news of honour killings came from two national daily newspapers ("Radikal" and "Posta") between 2012 and 2014. From these reports, those concerning the male victims of honour killing were chosen and these news reports were analysed by the critical discourse analysis method. As a result of this analysis, it was found that the notion of honour is described through sexuality and the woman's body is similarly emphasized in news concerning both female and male victims. It further shows that honour is "cleansed" by the murder of those men who do not conform to this description. The murderers of men murdered in the name of honour can be those women whose honour is "blemished" or by the male relatives, fathers or brothers, while the murderers of those women killed in the name of honour are mostly men. One of the striking finds from this study is the news' reports repeated emphasis on the murderer's demand to regain his social respect by stating that he committed the crime on the basis of honour. This situation reproduces the sexist discourse about violence based on male hegemony. It was observed that words such as "honour" and "custom" are also employed in the headlines. It can therefore be said that this way of presenting these murders in news reports, itself contributes to the reflection of sexist ideology and sexual order stereotypes related to honour-based murders.

Keywords: Gender, Honour, Namus, Woman, Honour Killings

* Prof. Dr., Akdeniz Üniversitesi, Edebiyat Fakültesi, Sosyoloji Bölümü, Antalya.nadak@akdeniz.edu.tr 
Namus adına işlenen cinayetlerle ilgili araştırmalar incelendiğinde genellikle çalışmaların kurbanın kadın olduğu cinayetlere ilişkin akademik çalışmalar olduğu gözlenmektedir (Odeh 1996; Sev'er \& Yurdakul 2001; Grewal 2013). Ancak namus adına işlenen cinayetlerin kurbanları sadece kadınlar değildir. Erkekler de bu cinayetlere kurban gidebilmektedir. Bu çalışmada namus adına işlenen cinayetlerin erkek kurbanlarının gazete haberleri üzerinden incelenmesi amaçlanmaktadır. Namus, her ne kadar kadın bedeni ve cinselliği üzerinden tanımlansa da (Coomaraswamy 2005; Shier \& Shor 2016) hem kadınlar hem de erkekler açısından bağlayıcı olmakta "namusu kirlenen" kadınlar ölümle cezalandırıldığı gibi kadınların "namusunu kirleten" erkekler de namus koruyucusu erkekler tarafından öldürülebilmektedir. Hatta Zvinkliene (2010, 534) bazı Müslüman toplumlarda namus adına cinayet işleyenlerin "kahraman" olarak dahi görülebildiği ve damgalanmaya maruz kalmadığına dikkat çekmektedir. Bu bağlamda namus erkek ve kadınlara farklı sorumluluklar yükleyen cinsiyetçi bir yapıya sahiptir (Doğan 2016, 92-94).

Namus adına işlenen cinayetlerin dinamiklerini anlayabilmek, bu cinayetlerin işlendiği toplumlarda namus kavramının nasıl tanımlandığıyla yakından ilgilidir. Zvinkliene (2010, 532) namus kavramının yorumlanmasına ilişkin iki akademik gelenek olduğunu belirtir: Namus bir taraftan erdem diğer taraftan üstünlük/hiyerarşi olarak tanımlanır. Her iki durumda da, namus, cinsiyete dayalı bir değer sistemi olarak düşünülür. Erdem olarak namus, çoğunlukla kadınlarla ilişkilidir, üstünlük/hiyerarşi olarak namus ise erkeklerle bağlantılıdır. Toplumsal cinsiyet kimliğinin oluşturulmasında köşe taşı olan namus, farklı kültürlerde farklı tanımlara sahiptir ve kavramının en görünür anlamı cinsel davranışa ilişkin "saflığın korunması", evlendikten sonra da sadece eşine sadık kalma şeklinde tanımlanmaktadır (Bağlı \& Özensel 2011, 39). Namus ile kadın cinselliği ve kadın bedeninin kontrol edilmesi arasında yakın bir bağ vardır. Foucault (1993, 30-35) yurttaşların her birinin cinselliğin kullanımını denetleme yeteneğine sahip olması gerektiğini vurgular. Kadının bekareti, evlilik dışı cinsel ilişkisinin olmaması, düzgün giyinmesi, bir kadından "beklenen" şekilde davranması, geleneklere uygun görevlerini yerine getirmesi namusla yakından ilgilidir (Türkiye'deki Namus Cinayetlerinin Dinamikleri, Eylem Programı İçin Öneriler Sonuç Raporu 2005, 16). Toplumda kadınları baskılayan namus, erkeklerin yaşamlarının odağına da kadınların 'namus bekçileri' olma görevini koymaktadır.

Bilgili ve Vural tarafından aktarılan bir araştırmanın sonuçlarına göre namus nedir sorusuna katılımcıların \%32,9'u karım, bacım, annemdir yanıtını verirken töre nedir sorusuna katılımcıların \%57,2'si atalarımızın koyduğu kurallardır yanıtını vermiştir. Aynı araştırmada kadının görevi nedir sorusuna ise, katılımcıların \%49,9'u cinsel saflığını korumak cevabını verirken namusu korumak görevinin katılımcıların \%23,9'u babanın, ağabeyin, \%21'i ise ailedeki tüm erkeklerin görevi olduğunu belirtmiştir. (http://www.voanews.com/turkish/archive/2005-10/ 2005-10-24-voa14.cfm'den akt. Bilgili \& Vural 2011, 67). Araştırma sonucundan da anlaşılacağı üzere namus kadın ve erkeklerin toplumsal yaşam içerisinde korumaları gereken en değerli şeylerden birisidir.

Sirman'a $(2006,49)$ göre “Bir erkek, kendi sorumluluğu altındaki kadın ya da kadınların cinselliğini kontrol edemezse 'namussuz' olurken, namussuz kadın kendi cinselliği üzerinde kontrolü gerçekleştiremeyendir. Namussuz erkek, sözüne güvenilmeyen, hem kendi cinselliğine hem de korumakla yükümlü olduğu kadının cinselliğine söz getirendir". Bu bağlamda hem kadın hem de erkek toplumda saygınlığını korumak adına namus cinayetlerinin faili veya kurbanı olabilmektedir. Öyleyse namus, uğruna can verecek veya can alacak kadar önemli bir olgu olarak karşımıza çıkmaktadır. Buradan hareketle Peristiany $(1966,183)$ hayatın anlamı olarak kabul edilen "namus" kavramının "utanma" kavramı ile birleştiğinde toplumsal beklentilere aykırı olarak namusa yönelik tehdidi şiddet kullanmaksızın ortadan kaldırmanın neredeyse 
imkânsız olduğunu vurgulayarak namus cinayetlerini işaret etmektedir.

Namus cinayetlerinin dar ve geniş anlamda tanımlanabileceğini belirten Shier ve Shor $(2016,1165)$ dar anlamda namus cinayetlerinin aile içinde işlenen diğer cinayetlerden ayırıcı dört özelliğine dikkat çeker:

İlk olarak, namus cinayetleri planlanır ve mağdurun (genellikle genç bir
kadın) evlilik ailesinden ziyade (örneğin, bir baba, erkek kardeş, kuzen
ya da babanın amcası) içine doğduğu doğum ailesinin bir üyesi tarafin-
dan gerçekleştirilir. İkincisi, fail, genellikle tek başına hareket etmez.
Aksine, cinayeti onurlandırmak için hazır olan bir topluluğun desteğini
alır. Böylece sadece bireyin değil topluluğun namusu da korunmuş olur.
Üçüncüsü, şüphe genellikle cinayeti işlemek için yeterlidir ve cinsel
sinırların ihlal edilmesine dair hiçbir kanıt veya delil beklenmez. Son
olarak, namus cinayetleri önceden tasarlanmıştır; bunlar "tutku suçları"
na göre daha fazla planlanmış suçlardır (Shier \& Shor 2016, 1165).

Namus cinayetlerinin yukarıda sıralanan ayırt edici özellikleri incelendiğinde Hadidi vd. (2001, 357) tarafından Ürdün'de gerçekleştirilen bir araştırmada namus adına işlenen cinayetlerin büyük çoğunluğunun kurbanların kardeşleri tarafından gerçekleştirildiği gözlenmiştir. Namus adına işlenen cinayetlerin Türkiye'de de alıntıda vurgulandığı gibi ait olunan topluluğun desteğinin alınarak ve planlı bir şekilde gerçekleştirildiği görülmektedir. Bu bağlamda işlenen cinayetlerde aile namusunu korumak adına alınan kararların kolektif olarak aile meclisinde alındığı ve cinayetin planlandığına rastlanmaktadır. Doğan (2016, 92-94) Türkiye'de gerçekleştirdiği çalışmasında namusa ilişkin toplumun belirlediği sınırların aşıldığına ilişkin herhangi bir dedikodu ve şüphenin bile kanıtlanmasına ihtiyaç duyulmaksızın namus adına cinayet işlenmesine neden olabileceğine ve namusun kırılgan bir yapısının olduğuna dikkat çekmektedir.

Shier ve Shor'un $(2016,1165)$ belirttiği gibi Hossain ve Welchman (2005)'e göre de "tutku" ve "namus" suçları arasında sıklıkla kabul edilen farklılıklardan birisi, failin kurbanla olan ilişkisidir. Tutku ve aşk cinayetlerinde failler genellikle kurbanla arasında belli bir yakın ilişkinin olduğu eşi veya sevgilisi iken namus cinayetlerinde fail kurbanın ya sevgilisi, eşi gibi partneri olabileceği gibi babası, erkek kardeşi ya da kuzeni gibi yakın bir erkek akrabası olabilir. Buradan hareketle namus cinayetlerinde failler genellikle kurbanın erkek yakınlarıdır.

Mojab’a $(2006,41)$ göre ataerkillik erkek egemenliğini üretir ve kültürü, dili, dini, eğitimi, ekonomiyi ve benzeri tüm sosyal yapılanmaları kendisini yeniden üretmek için kullanır. Şiddet, erkek egemenliğini yeniden üretmenin araçlarından biridir. Bu bağlamda namus adına işlenen cinayetler de erkek egemenliğini yeniden üreten bir araçtır ve medya şiddetin yeniden üretiminde önemli bir işleve sahiptir.

\section{Gazetelere Yansıyan Namus Cinayetlerinde Söylem}

Kadın ve erkeklere ilişkin farklı namus ölçütlerinin olduğu toplumda namus adına işlenen cinayetlerin oluşmasında, devam etmesinde ve yeniden üretilmesinde hiç kuskusuz en etkin araçlardan birisi de medyadır. Medyada yer alan şiddet haberleri, şiddet olaylarının olumsuz toplumsal etkilerine dikkat çekilmesi açısından sorunun çözümüne katkı sunabileceği gibi şiddeti normalleştirerek ve hatırlatarak toplumsal hafızaya kazınabilmektedir. Buradaki can alıcı nokta medyanın şiddet haberlerini nasıl sunduğu daha doğrusu haberleri okuyucuya nasıl bir söylemle ilettiğidir.

Bulut (2008, 68) Türk basınının, özellikle 2000'li yıllarda "töre” ilgili haberleri yoğun bir 
şekilde işleyerek toplumsal bir sorunu gündeme taşıdığını ve gündemde tutmayı başardığını vurgulayarak basındaki "töre" ile ilgili haber metinlerinin bir taraftan gündemi belirlerken bir taraftan da basının bu konudaki görüşünü ve olaya nasıl bakılması gerektiğini yansıttığını belirtmektedir. Basın bir taraftan namus adına işlenen cinayetlerinin sosyal bir sorun olarak tanımlanmasına katkı sağlarken diğer taraftan kullandığı dil ve söylem aracıllığıla bu cinayetlerinin yeniden üretimini sağlayabilmektedir.

Günümüzde eril şiddetin ortaya çıkışı ve kanıksanarak yeniden üretilmesinde önemli araçlardan olan medyada yer alan haberler mevcut güç ilişkilerini sürdürmeye neredeyse adanmış metinlerdir (Dursun 2008, 57). Haberlerde gücün ya da güçlünün doğru ve yanlış hâkim hale gelmesi, içinde yaşadığımız toplumsal alanın özelliği ile yakından ilgilidir. Dursun'un da $(2008,58)$ belirttiği üzere çeşitli güç ilişkileriyle hareketlenen toplumsal alanla bağlantımızı kuran anlam çerçeveleri olarak haberler bu ilişkileri ters yüz eden değil ufak rötuşlarla devam ettiren onlara makullük atfeden alanlar olmaya eğilimlidir.

Haber medyası toplumda var olan değer ve normları kendi ideolojik öncülleri bağlamında içerikleri ile sosyal gerçekliği inşa etmektedir. Ataerkil değerler çerçevesinde oluşturulan haber içerikleri okuyucuya ulaştığında toplumun eril değerleri aynı şekilde yeniden üretilmektedir. Soothill ve Walby (1991 akt. Carll 2003, 1603) İngiltere'de cinsel suçlarla ilgili gazeteleri inceledikleri çalışmalarında medyanın "cinsel suçların erkek ve kadınların toplumdaki konumu ile ilişskili olabileceğini düşünme" konusunda isteksiz olduklarını bulmuşlardır.

Carlyle ve arkadaşları (2008) eleştirel bir mercekten medyaya bakarak medyanın toplumsal alandaki şiddeti önlemek ya da önlenmesine katkıda bulunmak yerine içeriksel bir çerçeve çizmeksizin, tek başına yaşanan şiddet ile ilişkili bireysel durumlara odaklanma eğiliminde olduğuna vurgu yapmaktadırlar.

Haber anlatılarında olaylar sadece belirli bireylerin eylemleri olarak sunularak kişiselleştirilmekte böylece toplumsal olay ve olguların ardındaki toplumsal ve kültürel bağlamın sorgulanmas1 engellenerek sosyal sorunlar bireysel sorunlar olarak resmedilmektedir. Bu bağlamda namus cinayetleri kişiselleştirilerek bireylerarası sorunlar sonucu ortaya çıkan durumlarmış gibi haberlere yansitılmakta ve bu cinayetlerin arkasında yatan sosyal ve kültürel dinamikler göz ardı edilmektedir. Dursun'un $(2008,84)$ da vurguladığı gibi şiddete yol açan değer yargılarının, anlamların, ideolojilerin soyut işleyiş mekanizmaları haberde görülmemekte habere konu olan olay sadece söz konusu kadın ve erkeğin arasındaki ilişkinin dinamiğinden kaynaklanan ve özel/mahrem bir durummuş gibi sunulabilmektedir.

Sonuç olarak gazetelerde sunulan haberler ilettikleri mesajlar aracılığıyla habere ilişkin sosyal gerçekliğin inşasında ve okuyucu tarafından anlamlandırılmasında önemli bir role sahiptir. Dil vasıtasıyla gerçekleşen bu inşa ve anlamlandırma süreci toplumsal cinsiyet bağlamında da toplumdaki mevcut güç ve iktidar ilişkilerinden bağımsız değildir.

\section{Metot}

Medyanın kurbanın erkek olduğu namus adına işlenen cinayetleri yansıtma biçiminin incelendiği bu çalışmada farklı yayın politikalarına sahip iki gazetede (Posta ve Radikal) yer alan namus adına işlenen erkek cinayet haberleri eleştirel söylem analizi yöntemiyle çözümlenmiştir.

Eleştirel söylem analizi güç ilişkileri, değerler, ideolojiler, kimlik tanımlamaları gibi çeşitli toplumsal olguların dilsel kurgulamalar yoluyla bireylere ve toplumsal düzene nasıl yansıdığ 1 ve nasıl işlendiği ile ilgilenir (van Dijk 2003). Dilin kullanım biçimi ve işlevlerini inceleyen söylem analizi haber metinlerinde kullanılan dil aracılığıyla eşitsizliğin ve tahakküm ilişkilerinin yer aldığı toplumsal sistemin nasıl yeniden üretildiğini ortaya çıkarmayı amaçlar. $\mathrm{Bu}$ 
bağlamda kadın-erkek arasında toplumda var olan güç, iktidar ve tahakküme dayalı eşitsizliklerin namus adına cinayetler özelinde gazetede yer alan haber söylemlerine dil aracılığıyla nasıl yansıdığı ve nasıl yeniden üretildiğini inceleyebilmek eleştirel söylem analizi yöntemiyle mümkün görünmektedir.

Bu çalışmada 2012, 2013, 2014 y1llarına ait Posta (sırasıyla 3+7+7=17 haber) ve Radikal (sırasıyla $3+2+5=10$ haber) gazetelerinde kurbanın erkek olduğu 27 haber incelenmiştir. 5 erkek cinayeti her iki gazete tarafindan haberleştirilirken 10 namus cinayeti olayı Posta, 2 namus cinayeti haberi de sadece Radikal gazetesi tarafından haber olarak verilmiştir. Sonuçta 17 erkek cinayeti olayı iki gazetede 27 habere konu olmuştur.

Haberler iki tema çerçevesinde incelenmiştir:

- Namus ve Namus Cinayetlerinin Tanımlanmas1,

- Namus Adına İşlenen Cinayetlerde Toplumsal Boyut

\section{Araştırmada Verilerinin Çözümlenmesi}

Haberlerdeki namus bahaneli cinayetleri eleştirel söylem analiziyle incelemeden önce haberlere konu olan cinayetlere ilişkin sosyo-demografik özelliklere yakından bakmak haberleri çözümleyebilmek için faydalı olacaktır.

Haberlerde cinayet sonucu öldürülen erkeklerin yaşları 16-55 yaş arasında değişirken faillerin yaşları da benzer olarak 17-58 yaş aralığındadır. Bu veriler Türkiye'de 81 ilde İl İnsan Hakları Başkanlığı'nın 2003-2007 yılları arasında gerçeklesen töre ve namus cinayetlerine ilişkin topladığı verilerle benzerlik taşımaktadır. Söz konusu çalışmada cinayeti işleyenler/ sanıklar içerisinde çocukların oranı oldukça düşüktür (\%9). Kurbanın erkek olduğu namus adına işlendiği belirtilen 17 cinayet haberinde faillerin 5 tanesi kadın 12 tanesi erkektir. $\mathrm{Bu}$ durum cinayet işleyen faillerin büyük çoğunluğunun erkek olduğu suç literatürüyle uyumlu gözükmektedir.

Haberlerde faillerin ne iş yaptıkları araştırıldığında haberlerin yaklaşık yarısinda (5 olay ve 9 haber) failin ne iş yaptığı belirtilmektedir. Faillerin yaptıkları işlerin belirtildiği haberlerde 1 failin inşaat işçisi, 1 failin cep telefonu ticaretiyle uğraştığı, 1 failin tarım işçisi, 1 failin hurdac1, 1 failin (3 haber) öğretim üyesi, 1 failin de ev kadını ve tarım işçisi olarak çalıştığı bilgisine ulaşılmıştır.

17 failden 5 tanesinin kadın olduğu araştırma kapsamındaki cinayetlerde erkekler daha çok akrabası olmayan kişilerce öldürülmüşlerdir. Sadece iki olayda erkek kurbanlar akrabaları tarafından öldürülmüşlerdir. $\mathrm{Bu}$ haberlerin ilkinde

Tablo 1. Faillerin Erkek Kurbanla Akrabalık Durumu

\begin{tabular}{|l|c|}
\hline Akrabalık Durumu & Cinayet Sayısı \\
\hline Failin kocası & 1 \\
\hline Failin kız kardeşinin sevgilisi & 1 \\
\hline Failin akrabası & 1 \\
\hline Failin iş arkadaşı & 2 \\
\hline Failin karısının iş arkadaşı & 1 \\
\hline Failin arkadaşı & 1 \\
\hline Failin kızının tecavüzcüsü & 1 \\
\hline Failin kız kardeşinin tecavüzcüsü & 1 \\
\hline Failin tecavüzcüsü & 1 \\
\hline Failin sevgilisi & 2 \\
\hline Failin eşinin sevgilisi & 1 \\
\hline Failin komşusu & 1 \\
\hline Failin nişanlısını fuhuşa zorlayan kişi & 1 \\
\hline Akraba değil & 2 \\
\hline Toplam & 17 \\
\hline
\end{tabular}
haberde akrabalık derecesi belirtilmeden akrabası tarafından öldürüldü ifadesi yer alırken diğer olayda kadın fail kendisini aldattığı için eşini öldürmüştür. Kurbanın kadın olduğu namus 
cinayetlerinde kadınlar genellikle babası, erkek kardeşi, erkek kuzenleri gibi akrabaları tarafından öldürülürken (Shier \& Shor 2016, 1165) namus adına işlenen cinayetlerin erkek kurbanlarının failleri büyük çoğunlukla akraba olmayan erkeklerdir. Genel arak suç literatürü incelendiğinde kamusal alanda tanımlanan erkekler tanımadıkları erkekler tarafindan şiddete uğrayıp öldürülmekteyken özel alanda konumlandırılan kadınlar namus cinayetine kurban edildiklerinde en yakını erkekler tarafından öldürülmektedirler.

Tablo 2. Faillerin Öldürme Gerekçeleri

\begin{tabular}{|l|c|c|}
\hline Öldürme Nedenleri & Olay Sayısı & Haber Sayısı \\
\hline Namus meselesi & 1 & 1 \\
\hline Cinsel içerikli sözlerle taciz & 1 & 1 \\
\hline Zaafı olan kadını kıskanma & 1 & 3 \\
\hline Karısı/kocası/eski eşi ile ilişki yaşaması & 5 & 6 \\
\hline Taciz/tecavüz veya tecavüz sonucu hamilelik & 7 & 11 \\
\hline İlişkiye girip nişanlanmama & 1 & 4 \\
\hline Fuhuşa zorlama & 1 & 1 \\
\hline Toplam & 17 & 27 \\
\hline
\end{tabular}

Cinayetlerin neredeyse tamamı cinsellikle bağlantılı nedenlerle gerçekleştirilmiştir. Cinayetlerin yaklaşık yarısında fail kendisi, kızı, karısı, kardeşine cinsel taciz ya da tecavüzde bulunan erkeği "namusunu temizlemek" adına öldürmüştür. 17 namus adına işlenen erkek cinayetinin 5 tanesinin faili kadındır ve kadınların tamamı kendilerine tecavüz ettiğini iddia ettikleri erkekleri öldürmüşlerdir. Erkek cinayetlerinin yaklaşık üçte birinde ise fail eşi veya eski eşiyle duygusal veya cinsel ilişki yaşayan erkekleri öldürmüştür. Geleneksel ataerkil bakış açısına göre cinsellikle ilgili toplum tarafindan konulan sınırların aşılması içinde bulunulan grubun bu durumdan utanç duyması ile sonuçlanmaktadır. Yirmibeşoğlu'na $(2007,50)$ göre namus adına işlenen cinayetlerin ortak özelliklerinden birisi faillerin bu cinayeti bilinçli bir şekilde işleyerek utancın kaynağını ortadan kaldırmakla namusun ve şerefin temizleneceğine olan inançtır. Verilerde bu durumu doğrular niteliktedir.

\section{Namus ve Namus Cinayetlerinin Tanımlanması}

Namus kavramı kadın bedeni ve cinselliği üzerinden tanımlanmakta ve kadından evlilik dışı cinsel ilişki yaşamaması, cinsel saflığı ve bekaretini koruyarak toplumun kadından beklediği rol gerekleri ve beklentilerine uygun davranması beklenmektedir. Erkekten ise kendi sorumluluğu altındaki kadınların beden ve cinselliklerini kontrol etmesi beklenmektedir. Gazetelere yansıyan haberlerin tamamında kadın failler (17 failden 5'i kadındır) kendilerine tecavüz ettiğini iddia ettikleri kişileri öldürmüştür.

Nevin Ylldirım, kendisine silah zoruyla tecavüz ettiğini ileri sürdüğ̈̈ 2 çocuk babası 35 yaşındaki Nurettin Gider'i 28 Ağustos 2012 gecesi tüfekle vurdu, başını kesip bir çuvala koyarak, 'Işste namusuma uzananın kellesi' diyerek köy meydanına attı (20 Ağustos 2013, Posta).

...Daha önce kendisini kaçırıp tecavüz eden ve yeniden görüşmek isteyen 43 yaşındaki Ali Kalkan'ı randevu verdiği otogarda sırtından bıçaklayarak öldüren ayn yaştaki evli Nafiye Kaçmaz beraat etti... (10 Eylül 2012, Radikal). 
Akın Tokdemir'in kiz kardeşiyle iliş̧kiye giren Onur Sandal'ın nişanlanmayı kabul etmemesi üzerine, babası Ahmet Tokdemir ile önce bıçak ve falçatayla vücudunun 65 yerinden yaralayıp işkence yaptıkları, ardından da can çekişirken diri diri topră̆a gömdükleri belirlendi (16 Kasım 2014, Radikal).

Yukarıdaki örnekte Nevin Yıldırım kendisine zorla tecavüz ettiğini ileri sürdüğü Nurettin Gider'i öldürmekle kalmayıp başını kesip köy meydanına atarak namusla ilgili katı ve ağır yaptırımları hatırlatarak ataerkil namus anlayışı toplum gözünde pekiştirmektedir. Benzer şekilde Nafiye Kaçmaz ise kendisine tecavüz eden Ali Kalkan'a otogar gibi geniş kalabalıkların bulunduğu bir ortamda randevu vererek büyük bir insan topluluğunun içinde tecavüzcüsünü öldürerek toplumsal saygınlığını tekrar talep etmektedir. Akın Tokdemir ise "sorumluluğu altındaki" kız kardeşiyle ilişkiye giren Onur Sandal'1 nişanlanarak kardeşinin "namusunu temizlemediği" için bıçaklamıştır.

Şırnak Adliyesi'nde bugün devam eden duruşma öncesinde yaya olarak Cumhuriyet Meydani'nda yürüyen Tunç, tabanca ile vuruldu. Vuran kişi, çevrede bulunanların kendisine müdahale etmemesini isteyerek, 'Namus meselesi" dedikten sonra kayıplara karıştı (26 Aralık 2013, Posta).

Konya'da bir kadın, başka bir kadınla ilişkisi olduğunu iddia ettiği kocasını bıçaklayarak öldürdü. Gözaltına alınan kadın gazetecilere 'Namus cinayeti. Çekin beni' dedi (21 Ekim 2012, Posta).

Failler haber metinlerine bu cinayetleri namus gerekçesiyle işlediklerinin geçmesini israrla istemektedirler. Konya ve Şırnak'ta gerçekleşen cinayet haberlerinde bu durum açıkça gözlenmektedir. Haber metninde namus konusuna yapılan bu vurgu namus cinayetlerinin toplum tarafından kabul görerek meşrulaşmasına ve namusa ilişkin toplumsal değer ve normların yeniden üretilmesine katkı sağlamaktadır.

- "Kocasinı öldüren kadin: Namus Cinayeti"

- Ormandaki vahşette namus cinayeti iddiası

- Cezaevi önünde "namus" infazı

- "Namus meselesi"

Yukarıdaki haber başlıklarında olduğu gibi 'namus' kavramının haberin en etkileyici kısmı olan başlıkta kullanılması da haber aracılığıyla namus adına işlenen cinayetlere ilişkin toplumsal değer ve normların pekişmesine yardım etmektedir.

Denizli'de 40 yaşındaki İ.Ç., boşandĭ̆ l eşine ilgi gösterdiğini iddia ettiği arkadaşı 41 yaşındaki Salim Yalçı'yı, balkondan tırmanıp evine girdikten sonra bıçaklayarak öldürdü. Ardından cinsel organını kesip ağzına koy$d u$. I.Ç., olay yerinde polis ekipleri tarafindan gözaltına alındı (29 Kasim 2013, Posta).

Hall $(1973,183)$ olayları belli kişilerin yaptığı ve olayın motor gücünün bu kişiler olduğu şeklinde yansıtılan haberlerin toplumsal/kurumsal bağlamından soyutlandığına dikkat çekmektedir. Bu durumu Denizli'de İ. Ç. nin Salim Yalçı'yı öldürmesi haberinde gözleyebiliriz. Olay bireysel bir durum gibi anlatılarak toplumsal bağlamından koparılıp kişiselleştirilmektedir. Ancak ataerkil değerler çerçevesinde bir erkeğin boşanmış olduğu eski karısı dahi olsa karısına başka bir erkeğin ilgi göstermesi geleneksel değerler çerçevesinde kabul edilebilir bir durum değildir ve erkeklik değerlerini zedeleyerek erkeğin toplumda statü kaybetmesine neden olan, şerefi ve 
onuruyla yaşamasına engel bir durumdur. Kişisel bir durum olarak yansıtılan cinayet aslında toplumsal/kurumsal bağlamından soyutlanarak tanımlanmaktadır. Ayrıca fail İ. Ç.'nin Salim Yalçı'yı öldürmekle yetinmeyip cinsel organını kesmesi bu olayı, sadece iki kişi arasında yaşanan bireysel bir sorun olmaktan çıkarıp cinsellik ve cinselliğin kimlerle ve nasıl yaşandığına ilişkin toplumsal değer ve normların, ataerkil ideolojinin de hesaba katılması gereken toplumsal bir bağlama taşımaktadır. Kalav'da $(2012,158)$ ataerkilliğge dayalı toplumlarda grubun üremesinin bireylerin cinsel davranışına bağlı olduğunu bu nedenle de bireysel cinselliğin toplumun tümünün denetim ve kontrolüne tabi namus olgusuyla şekillenmek zorunda bırakıldığına dikkat çekmektedir.

\section{Namus Adına İşlenen Cinayetlerde Toplumsal Boyut}

Namus adına işlenen cinayetler bir kişi tarafından işlense de kolektif bir özellik taşır. Arkasında geleneksel sosyal yapıya dayanan güçlü bir toplumsal baskı vardır. Bu tür bir baskıya neden olan düşün sistemi öncelikle erkekler olmak üzere toplumun pek çok üyesi tarafından onaylanmaktadır (Çetin 2012, 10). Namus adına işlenen cinayetlerde fail, genellikle tek başına hareket etmez ait olduğu topluluğun da desteğini alarak cinayeti onurlandırır ve bu sayede bireyin yanı sıra topluluğun namusu da korunmuş olur. Aşağıdaki ilk örnekte Recep Öncü cinayetin tek başına bir kişi tarafindan değil aile meclisinin kararı ve desteğiyle gerçekleştirildiği belirtilerek namusun tüm topluluğun namusuna nasıl dönüştüğünü gözler önüne sermektedir. Bireyselleşmenin ön planda olduğu toplumlarda cinsellik bireylerin sorumluluğunda olup özel alanla ilgiliyken İnkaya köyünde yaşanan cinayette olduğu gibi kolektif toplumlarda evlilik dışı deneyimlenen cinsellik ve hamilelik aile meclisinin müdahale edebildiği bir zemine taş1nabilmektedir. Ayrıca söz konusu cinayet haberinde eylem anonimleştirilerek haberde fail görünmezleştirilmektedir.

...Dayı Recep Öncü'ye göre cinayet sadece bir kişinin yapabileceği bir iş değil. Öncü, "Bu ilişki meydana çıkınca aile bunu hazmedemedi. Namus meselesi yaptılar ve aile karart ile benim yeğenimi hunharca öldürdüler dedi... (13 Eylül 2012, Posta).

Kulp'un İnkaya Köyü'nde yaşayan E. P. 2009 yllında hamile kaldı. Aile meclisi tarafindan sorgulanan E. P. evli ve 1 çocuk babası olan teyzesinin oğlu Muharrem Yıldırım'dan hamile kaldığını söyledi (23 Ekim 2012, Radikal).

Namus adına işlenen cinayetlerde şüphe genellikle cinayeti işlemek için yeterlidir ve cinsel sınırların ihlal edilmesine dair hiçbir kanıt veya delil beklenmez. En küçük bir dedikodu cinayete neden olabilir. Aşağıdaki alıntıda Tugay Çelik hiçbir kanıt aramaksızın karısıyla cinsel ilişkiye girdiği konusunda dedikodu yapan Efraim Çelik'i öldürmüştür. Bu haberde ayrıca aile meclisi kararıyla ya da mahalle dedikoduları ve mahalle baskısı nedeniyle cinayetin gerçekleştirildiğine vurgu yapılarak fail görünmez hale getirilmekte böylece eylem gizlenmektedir. Aile meclisi kararıyla işlenen söz konusu cinayetler bu cinayetlerin bir anlık kıskançlık veya öfke ile işlenen tutku cinayetlerinden farklılı̆ğnı da ortaya koymaktadır. Namus adına işlenen bu cinayetler, topluluğun üzerinde konuşup aile meclisi aracılığıla cinayet kararı alarak planlı gerçekleştirdikleri cinayetlerdir.

Genel olarak namus adına işlenen cinayet haberlerinde failden ziyade kurbanın ön plana çıkarıldığı ve failin sorumluluklarının geri planda kaldığına tanık olunmaktadır. Haberde dikkat çeken bir diğer noktada failin eşinin dekolte giydiği ve bu konuda dedikoduların yapıldığı vurgulanarak cinayetin gerekçelendirilmesi ve fail ve eylemden çok dekolte giyen kadına ve 
onunla ilgili dedikoduya yer verilerek olayın magazinleștirilmesi söz konudur.

Adana'da eski ortağı Muhittin Kalkan'l, eşiyle ilişkisi olduğu söylentileri yüzünden bıçaklayarak öldürdüğ̈̈ iddiasıyla tutuklanan Diyaddin Görgen kendini savundu (18 Temmuz 2012, Posta).

...Tugay Çelik ile kuzeni Necmettin Çelik tarafindan öldürülen Efraim Türkmen'in, Tugay Çelik'in eşi H. Ç. ile 3 kez cinsel ilişkiye girdiğini anlatarak dedikodu yaptı̆̆ ileri sürüldü... Eşinin dekolte giyindiği dedikodularını köyde Efraim Türkmen'in yaydiğını düşünen katil şüphelisi Tugay Çelik'in Türkmen ile bir hafta önce aynı gerekçe ile kavga ettiği de ortaya çıktı... (20 Ağustos 2014, Posta).

Cinsellikle yakından ilgili olan aldatma, taciz ve tecavüz durumlarında "namusun kirlenmesi" ve haberlerde bu konuya yapılan 1srarlı vurgu okuyucunun gözünde cinayeti haklılaştırabilmektedir. Böylece fail eyleminden sorumlu tutulmamaktadır. Başka bir kadınla ilişkisi olduğu için kocasını öldüren kadınla ilgili haberde aldatma konusuna dikkat çekilerek kadının gazetecilere "Namus Cinayeti. Çekin beni" ifadesine yer verilmekte ve aldatmanın namusu kirlettiği gizli mesajıyla cinayet meşrulaştırılmaktadır. Kızını taciz eden adamı öldüren baba haberinde de cinayet bir nedene bağlanarak haklılaştırılmaktadır. Benzer bir durum kızına tecavüz eden kişiyi öldüren baba haberinde de gözlenmektedir. Şenay Ertan'ın “'Polisi bana tecavüz ettiği için öldürdüm' ifadesine manşetten veren gazete haberinde de cinayete bir neden bulunularak cinayet gerekçelendirilmektedir.

...Konya'da bir kadın, başka bir kadınla ilişsisi olduğunu iddia ettiği kocasını bıçaklayarak öldürdü. Gözaltına alınan kadın gazetecilere "Namus Cinayeti. Çekin beni" dedi (21 Ekim 2014, Posta).

Şırnak'ta $H$. F., geçen yll kızına tecavüz ettiği iddiasıyla tutuksuz yargılanan Salih Tunç'u sokak ortasında tabanca ile vurarak öldürdü. H. F., Tunç'a ateş ettikten sonra çevresindekilerin müdahale etmemesini isteyerek, 'Namus meselesi' dedi (26 Aral1k 2013, Posta).

Muharrem Y, 12 yaşındaki kızı T. Y'yi elle taciz ettiğini öğrendiği Mustafa Karakaş'ı, başına taşla vurarak öldürdü... (29 Mart 2012, Posta).

Şenay Ertan 'Polisi bana tecavüz ettiği için öldürdüm' dedi (27 Mart 2013 Radikal).

Medya yaptığı bilgilendirme yoluyla toplumu oluşturan bireylerin kanaat, değer, tutum ve davranışlarını etkileme gücüne sahiptir. Bu bağlamda medya bu makale özelinde de gazeteler, yaptıkları haberlerle toplumdaki mevcut değer ve normları kuvvetlendirebileceği gibi namus adına işlenen cinayetlerde olduğu gibi önemli toplumsal sorunlara neden olan düşün sistemini değiştirebilme gücüne de sahiptir.

Asuman'ın ya da yanındakilerin/yakınındakilerin üzerinde baskı meka-

nizması oluşturacak. İşinden de olan Asuman'in Konya gibi muhafa-

zakâr bir şehirde rahat nefes alması her dakika daha da zorlaşacak (15

Haziran 2014, Radikal).

$\mathrm{Bu}$ çalı̧̧madaki gazete haberlerinin içerik çözümlemesi sonucunda haberlerin genel olarak namus adına işlenen cinayetlere toplumsal bir sorun olarak dikkat çekmek ve farkındalık yaratmak yerine bunu bireyselleştirerek, magazinleştirerek gerekçelendirdiği anlaşılmaktadır. Ancak Asuman ile ilgili yukarıdaki haberde namus adına işlendiği belirtilen cinayetin Asuman'ın üzerinde nasıl bir baskı oluşturacağı vurgulanarak bu durumdan günlük yaşamının 
nasıl olumsuz etkileneceği dikkat çekerek gazete duyarlı bir tutum izlemiştir.

\section{Sonuç ve Değerlendirme}

Türkiye'de namus adına işlenen cinayetler konusunda çeşitli önlemler alınıp yaptırımlar uygulansa da cinayetler belli bölgelerde yaygınlığını korumaktadır. Namusa ilişkin ataerkil değer ve normlar maddi koşulların zamanla değişmesi ve kadın cinselliğini denetlemeyi zorlaştıran bazı değişmelere karşın direnç göstermektedir. Kardam (2003) bunun en önemli nedenlerinden birisinin söz konusu ataerkil değerlerin kadınlar tarafından toplumsallaşma sürecinde benimsenerek çocukların yetiştirilmesinde yeniden üretilerek yeni nesillere aktarılması olduğunu belirtir.

Ataerkil kültürde erkeklerin kadınları nesneleştirdikleri, bedenleri ve cinsellikleri üzerinde kontrol kurmak için uyguladıkları şiddet sadece erkek eylemleriyle yayılıp yeniden üretilmez. Günümüz iletişim çağında namus ve namus bahaneli cinayetlere ilişkin ataerkil ve hegemonik cinsiyetçi söylemin toplumun tüm kesimlerine ulaştırılarak ve yeniden üretilmesinde medyanın önemli bir etkisi söz konusudur.

Posta ve Radikal gazetelerinde yer alan namus adına işlenen erkek cinayetlerinin içerik çözümlemesinin yapıldığı bu çalışmada kurban olan erkeklerin yaşlarının 15-39 yaş aralığında faillerin ise kırklı yaşlarda yoğunlaştığı anlaşılmıştır. Faillerin çoğunun erkek olduğu namus cinayeti haberlerinde kadın failler daha çok kendilerine taciz ve tecavüzde bulunan erkekleri öldürmüşlerdir. Namus cinayetlerinin kadın kurbanlarının failleri büyük çoğunlukla yakın akrabaları iken erkek kurbanlar çoğunlukla akraba olmayan erkekler tarafından öldürülmüşlerdir. Bu durumun geleneksel cinsiyet rolleri çerçevesinde kadınların ev içi özel alanla erkeklerin ise ev dış1 kamusal alanla ilişkilendirilmesiyle yakından ilgili olduğu düşünülebilir.

Çözümleme sonucunda kurbanın erkek olduğu namus adına işlenen cinayet haberlerinde de kurbanın kadın olduğu namus cinayeti haberlerine benzer olarak namus kavramının kadın ve kadın bedeni üzerinden tanımlandığı ve ona zarar veren erkeklerin ölümle cezalandırılarak namusun "temizlendiği" vurgulanmaktadır. Haberlerde namus adına işlenen cinayetlerin toplumsal bir sorun olduğu vurgusu yapılmak yerine genellikle olaylar kişiselleştirilerek sosyal bağlamından kopartılmaktadır.

Namus adına işlenen kadın cinayetlerinin faillerinin büyük çoğunluğunu erkekler oluştururken namus adına öldürülen erkeklerin failleri, namusu "kirletilen" kadınlar veya onların baba, erkek kardeş gibi erkek yakınları olabilmektedir. Araştırmanın çarpıcı verilerinden birisi de haber metinlerinde failin cinayeti namus gerekçesiyle işlediğinin belirtilerek toplumdaki saygınlığın yeniden kazanma talebinin vurgulanmasıdır. Bu durum eril tahakküme dayalı cinsiyetçi şiddet söylemini pekiştirici bir rol oynamaktadır. Ayrıca bazı haber başlıklarında 'namus', 'töre' kavramlarının kullanıldığ 1 da gözlenmiştir. Bu durumun da haber aracılı̆̆ıyla namus adına işlenen cinayetlere ilişkin cinsiyet rejiminin ve cinsiyetçi ideolojinin pekiştirilip yeniden üretilmesine katkı sunduğu iddia edilebilir. Sonuç olarak namus adına işlenen cinayetleri basit bir şekilde kişisel husumet sonucu ortaya çıkan ölümler olarak görmek doğru değildir bunlar ataerkil ilişki biçimlerinin neden olduğu ölümlerdir ve sosyal bir sorun olarak tanımlanıp ataerkil değerler değişmedikçe de işlenmeye devam edeceklerdir.

\section{Yazarın Notu}

Çalışmanın ilksel biçimi daha önce Muenster/Almanya'da $16^{\text {th }}$ Annual Conference of the European Society of Criminology'de sözlü bildiri olarak sunulmuştur. 


\section{KAYNAKÇA}

Bağlı M. \& Özensel E. (2011). Türkiye'de Töre ve Namus Cinayetleri. İstanbul 2011.

Bilgili N. \& Vural G. (2011). "Kadına Yönelik Şiddetin En Ağır Biçimi: Namus Cinayetleri”. Journal of Anatolia Nursing and Health Sciences 14/1 (2011) 66-72.

Bulut M. (2008). "Bir Sosyal Temsil Araştırması: Medyada ve Üniversite Öğrencilerinde "Töre"nin Algılanışı”. Ç.Ü. Sosyal Bilimler Enstitüsü Dergisi 17/3 (2008) 63-78.

Carll E. K. (2003). "News Portrayal of Violence and Women: Implications for Public Policy". Am. Behav Scientist 46/12 (2003) 1601-1610.

Carlyle K. E., Slater M. D. \& Chakroff J. L. (2008). "Newspaper Coverage of Intimate Partner Violence: Skewing Representations of Risk". J Commun 58/1 (2008) 168-186.

Çetin İ. (2012). "Bir Bataklık Olarak 'Namusun Temizlenmesi' Mefhumu". Uluslararası Kattlımlı Kadına ve Çocuğa Karşı Şiddet Sempozyumu Bildiri Kitabı 1 (2012) 5-11

Coomaraswamy A. \& Sarathkumar S. (2005) "Önsöz Kadına Yönelik Şiddet ve "Namus Suçları". Namus Suçlar Paradigmalar ve Kadına Yönelik Şiddet. İstanbul 2005.

Doğan R. (2016). "Namus", "Töre" ve Eril Şiddet Yargıtay Kararlarl, Toplumsal Cinsiyet Kuramlart. Ankara 2016.

Dursun Ç. (2008). Kadına Yönelik Aile İçi Şiddet ve Haber Medyası: Alternatif Bir Habercilik. Ankara 2008.

Foucault M. (1993). Cinselliğin Tarihi. İstanbul 1993.

Grewal İ (2013). "Outsourcing Patriarchy". International Feminist Journal of Politics 15/1 (2013) 1-19

Hadidi M., Kulwicki M. A. \& Jahshan H. (2001). "A Review of 16 Cases of Honour Killings in Jordan in 1995". International journal of legal medicine 114/6 (2001) 357-359.

Hall S. (1973). "The Determinations of News Photographs". The Manufacture of News: Social Problems, Deviance and the Mass Media, Communication and Society". Beverly Hills: Sage Publications 176/1 (1973) 226-247.

Hossain S. \& Welchman L. (Eds.). (2005). Honour: Crimes, Paradigms and Violence Against Women. 2005.

İnsan Hakları Başkanlığı 2007 Töre ve Namus Cinayetleri Raporu (2008).

Kalav A. (2012). "Namus ve Toplumsal Cinsiyet". Akdeniz Insani Bilimler Dergisi/MediterraneanJournal of Humanities II/2 (2012) 151-163.

Kardam F. (2003). "Namus Gerekçesiyle Öldürülme ya da Kendi Canına Kıyma: Kadın Cinselliği Üzerinde Baskıların Benzer Koşullarda Farklı Sonuçları”. Toplumsal Cinsiyet, Sağlık ve Kadın, Hacettepe Üniversitesi Kadın Sorunları Araştırma ve Uygulama Merkezi (2003) 249-264.

Mojab S. (2006). "Namusun" Tikelliği ve "Öldürmenin" Evrenselliği: Erken Uyarı Sinyallerinden Feminist Pedagojiye". Namus Adına Şiddet-Kuramsal ve Siyasal Yaklaşımlar 7 (2006) 17-42.

Odeh L. A. (1996). Crimes of Honour and the Construction of Gender in Arab Societies. Feminism and Islam: Legal and Literary Perspectives, Reading, Berkshire, England: Ithaca Press and Centre for Islamic and Middle Eastern Law. London 1996.

Peristiany J. G. (1966). "Honour and Shame, the Values of Mediterranean Society". London (1966)

Sev'er A. \& Yurdakul G. (2001). "Culture of Honor, Culture of Change: A Feminist Analysis of Honor Killings in Rural Turkey". Violence Against Women 7/9 (2001) 964-998.

Shier A. \& Shor E. (2016). "Shades of Foreign Evil, Honor Killings and Family Murders in the Canadian Press". Violence Against Women 22/10 (2016) 1163-1188.

Sirman N. (2006). "Akrabalık, Siyaset ve Sevgi: Sömürge Sonrası Koşullarda NamusTürkiye Örneği”. Namus Adına Şiddet-Kuramsal ve Siyasal Yaklaşımlar 7 (2006) 43-45.

Soothill K. \& Walby S. (1991). Sex Crime in the News. Abingdon 1991.

van Dijk A. (2003). "Critical Discourse Analysis". The Handbook of Discourse Analysis (2007) 352-372.

Yirmibeşoğlu V. (2007) Toprağa Düssen Sevdalar: Töre ve Namus Gerekçesiyle İşlenen Cinayetler, İstanbul 2007.

Zvinkliene A. (2010). "Honour Killings in Modern Societies: A Sociological Perspective". Islam and Civilisational Renewal 1/3 (2010) 532. 